\title{
Letter by the President of the European Council and Belgian Prime Minister, Guy Verhofstadt
}

\section{By Guy Verhofstadt}

Suggested Citation: Guy Verhofstadt, Letter by the President of the European Council and Belgian Prime Minister, Guy Verhofstadt, 2 German Law Journal (2001), available at http://www.germanlawjournal.com/index.php?pagelD=11\&artID=121

[Editorial Note: Letter by Mr Guy Verhofstadt, read during the ceromony in the Badia Fiesolana at the European University Institute's 25th Anniversary proceedings on 7 November 2001. The Editors wish to express gratitude to President Masterson for allowing GLJ to publish Mr Verhofstadt's letter]

Dear Mr. President:

Accepting your invitation to join you on November 7 for the European University Institute's celebration of its 25th Anniversary filled me with great joy. It is therefore with greatest regret that I have to inform you that the international political context has forced me to thoroughly replan the following weeks and that I will, for this reason, not be able to attend the ceremony.

My envisioned attendance of the EUI's Anniversary ceremony was to give testimony of the immense appreciation by the European Council as well as by my country for the work that the European University Institute, whose president you are, has achieved since its foundation with respect to both the research conducted and the training and education of researchers.

In my function as President of the European Council I would also like to underline the important work conducted by the Robert Schuman Center as to the reflections upon the process of European Integration in the context of the Union's enlargement. This work is essential and I would like no less than to encourage you with regard to its continuation.

My best wishes accompany you for the Institute's further activities and its radiant development.

Sincerely Yours,

Guy Verhofstadt 